\title{
Story Telling as an Effective Mean for Stimulating Students' Passion in Engi- neering Classes
}

Dr. Ibrahim Ali Olwi, King Abdulaziz University

Faculty member at the aeronautical engineering department since 1984. Had been in charge of gifted students programs for over a decade. His passion is simplifying science to the public. Currently is in charge of students innovations at the university level. 


\title{
Storytelling as an Effective Mean for Stimulating Students' Passion in Engineering Classes
}

\begin{abstract}
Storytelling was employed as a powerful tool in stimulating students' interest in the classroom of a sophomore level course in engineering design. Over two years, students' assessment of the methodology was obtained through a survey that incorporated students that have and not have taken the course. The outcome of students' satisfaction and support of telling stories by the instructor was overwhelming among both groups of students. The impact was not targeted towards just creating passion in the classroom, but the active participation and reflection on the stories was sought to lead to ethical values pedagogy. To gain multi-cultural awareness and global experience, stories from international magazines were addressed along with the instructor's experience in higher education (abroad) and consultancy in international companies.
\end{abstract}

\section{Introduction}

Higher education is under severe pressure from the community, because of escalating education fees, to produce high quality graduates. Class room lectures are expected to play a vital role in achieving that goal ${ }^{1}$. Universities are expected to improve the status of teaching and enhance the experience of students' learning in the classroom.

Students should learn in the colleges of engineering the skill of coming up with solutions and the art of applying them. However, engineering education deals primarily with numbers. Therefore, many students act as calculators. They lack passion for what they are being taught. The challenge is to create students' interest in the class, which directly reflects in achieving the course learning outcomes.

One of the best means to establish this is by telling stories ${ }^{2}$. Stories pose a profound tool for making sense of the subject being taught ${ }^{3-5}$. Since they deal with actual cases every day, it is common practice in the colleges of medicine to tell stories (cases) as part of medical education. It is not as simple in the colleges of engineering. It takes an extra effort in the field of engineering education to come up with meaningful relevant stories, especially as many engineering faculty members do not have any professional experience other than teaching and conducting lab research.

The narrative instinct had been the fundamental scheme for mankind communication. Stories were used across mankind history to entertain the listeners. At the same time, storytelling has been the basic mean for capturing attention throughout civilizations. Not only information is revealed through stories, but more important is the logic built through the lessons each story holds in it. It offers sharing of ideas and experiences, i.e. it is not a monologue, rather a dialogue $^{6}$. Thereby, higher levels of learning (in Blooms taxonomy ${ }^{7}$ ) could be achieved through storytelling. Johns and Sanguedolce ${ }^{8}$ provided such evidence through a case where story gathering and telling was employed to improve higher order thinking skills through personal and peer assessment. 
Furthermore, storytelling could take on the form of a digital one, since digital technology is offering new dimensions in education. Robin ${ }^{9}$ argues that computers promote creative storytelling. This would enable students to gain $21^{\text {st }}$ century literacy skills, thus empowering the classroom to meet its challenges.

The paper presents the students' assessment results of the idea of storytelling as a catalyst to their engagement in the class and as a means to enhance their understanding of the subject. It also addresses the learning outcomes attained. The study was conducted over two years in IE 202 (Introduction to Engineering Design II); a compulsory course offered to all sophomore students in the College of Engineering at the second semester.

\section{Levels of learning}

In addition to creating excitement in the class and building passion for science in the lecture, several levels of learning are to be gained from the methodology of storytelling. Alterio and McDrury ${ }^{10}$ have developed a five-stage approach for the complete levels of learning sought to achieve constructive learning through storytelling:

1. story finding,

2. story telling,

3. story expanding,

4. story processing and

5. story reconstructing.

The level of engagement in the case being presented in the paper covered all previous stages except the last one, as it requires students' preparation of their own stories and sharing them with the rest of the class in order to get peer-reflection; an issue that may not be covered within the time frame of the course. Already some faculty members, who heard of the initiative, questioned the possibility of invoking any material other than the original course material due to lack of time.

\section{Methodology}

The main ingredient for effective storytelling are being relevant to the course material and addressing the future profession of the students. This may not be easily applicable in all engineering courses. It is evident that the "Engineering Design" course is one of the best opportunities for employing storytelling in the class, as it provides the atmosphere for brainstorming, assessment, selection and implementation.

This approach of introducing stories in the class was employed casually over the past years in the course. However, during the last three semesters, it was consciously planned to have a story every class. At the end of each semester, a survey was conducted to assess the methodology employed. A total of eight sections were surveyed over the three semesters. The survey addressed the idea and its implementation through a detailed questionnaire of ten items. Recently, the gender effect was also examined as there were two sections of female students, and two sections of male students this past semester. 


\section{Sources of stories}

Faculty members should acquire a treasure of cases and stories. The sources for attaining them include, but are not limited to:

- personal experiences in daily life,

- technical experiences (if available) of consultancy services and non-academic tasks,

- stories watched or heard through various multimedia sources, and

- news available in science and engineering magazines.

The more one looks for chances, the more he/she will discover their abundance everywhere.

\section{Challenges}

It seems to be a joyful experience and an easy task to spend the lecture time telling stories, thereby creating passion within students towards the "scientific lecture". The fact of the matter is that it takes a great deal from the faculty member to get prepared for the class in order to invoke the appropriate stories to the subject matter being discussed. He/she had never been through this experience, and most probably had never been taught this way, nor had been trained on the effective and creative tips needed in the classroom to enhance the quality of teaching ${ }^{11,12}$.

In addition, some occasions would arise in the classroom where the faculty member's interference with a story of relevant wisdom is needed momentarily and cannot rely on the structured schedule of stories. Through the practice of preparing stories and delivering them, the faculty member would have built the adequate experience to invoke, in time, appropriate stories to deal with unexpected situations, especially when ethical aspects are challenged.

Naturally, narrating a story may not be exciting if it was more of a news-reading delivery. The faculty member should be pumped up with passion for teaching, and a believer in student development such that his enthusiasm is radiated to his or her students. This sense could be built through reading stories of success and essays on teachers ${ }^{13,14}$. At the same time, out of class meeting with the students to deal with their challenges creates connection with the students, and thereby motivates the instructor to get more engaged and play an active role in the class.

\section{Data collection}

The data for the study was collected through a survey to enable research-based evidence of the effectiveness of storytelling on students' excitement in class, engagement with the scientific subject, and learning levels. The survey started two years ago, as part of the exit survey, where students who had been through the experience where asked to assess the experience of having stories told to them as part of the lecture. At the beginning of this semester, input from students of the same course in sections with three other instructors who have never been through the experience was a new source of data to investigate the general perception of hearing stories among students. Being in a segregated education system, female students where part of the survey, as the author was the instructor for their sections of the same course through video conferencing. So the study incorporates the effect of gender. All in all, the total number of students involved in the study was 179 from ten sections over four semesters. 


\section{The survey}

The items addressed in the survey were as follows:

1. Stories overcome tediousness, and therefore increase my pleasure in the lecture.

2. Stories catch my attention and get me attached to the lecture such that I look forward to be in the lecture to hear a new story.

3. Stories provide examples explaining the scientific essence of that day's subject.

4. Stories add up to my expertise and heuristics, and provide a source of wisdom that I shall use in my life.

5. Stories increase my scientific background.

6. Stories augment my overall knowledge.

7. Actual stories cause more excitement and interaction than virtual ones.

8. Actual stories are more beneficial than virtual ones.

9. Stories are nice and beneficial but at the cost of the lecture time, thereby the scientific material is not fully covered.

10. Stories are a waste of time and have no outcome, so there is no need for them.

As one might notice, the last two items were intentionally not in favor of storytelling such that students filling the survey are conscious and aware of the scores they are putting. Very few cases had 5 in every item, and obviously were not considered in the study. The score used was 5 (totally agree), 4 (agree), 3 (undecided), 2 (don’t agree), and 1 (totally disagree).

\section{Results}

The results are presented in three categories. Table 1 presents the assessment of the male students who had been through the experience of listening to stories for one semester. The last column represents the percentage of students who "totally agree" or "agree" on the statement. The results in the table represent the outcome obtained from 89 male students taking the course in 5 sections over the last three semesters.

Table 1. Assessment results of male students having been through the experience.

\begin{tabular}{|l|c|c|}
\hline \multicolumn{1}{|c|}{ Item } & $\begin{array}{c}\text { Average } \\
\text { Score }\end{array}$ & $\begin{array}{c}\text { who } \\
\text { agree }\end{array}$ \\
\hline Stories overcome tediousness, and therefore increase my pleasure in the lecture. & 4.54 & $92 \%$ \\
\hline $\begin{array}{l}\text { Stories catch my attention and get me attached to the lecture such that I look } \\
\text { forward to being in the lecture to hear a new story. }\end{array}$ & 4.38 & $93 \%$ \\
\hline Stories provide examples explaining the scientific essence of that day's subject. & 4.49 & $87 \%$ \\
\hline $\begin{array}{l}\text { Stories add up to my expertise and heuristics, and provide a source of wisdom } \\
\text { that I shall use in my life. }\end{array}$ & 4.75 & $96 \%$ \\
\hline Stories increase my scientific background. & 4.49 & $89 \%$ \\
\hline Stories augment my overall knowledge. & 4.51 & $93 \%$ \\
\hline Actual stories cause more excitement and interaction than virtual ones. & 4.63 & $94 \%$ \\
\hline Actual stories are more beneficial than virtual ones. & 4.65 & $92 \%$ \\
\hline $\begin{array}{l}\text { Stories are nice and beneficial but at the cost of the lecture time, thereby the } \\
\text { scientific material is not fully covered. }\end{array}$ & 2.53 & $30 \%$ \\
\hline Stories are a waste of time and have no outcome, so there is no need for them. & 1.30 & $1 \%$ \\
\hline
\end{tabular}


On the other hand, the outcome obtained from 29 female students who took the course during the last semester is presented in Table 2.

Table 2. Assessment results of female students having been through the experience.

\begin{tabular}{|l|c|c|}
\hline \multicolumn{1}{|c|}{ Item } & $\begin{array}{c}\text { Average } \\
\text { Score }\end{array}$ & $\begin{array}{l}\% \text { who } \\
\text { agreed }\end{array}$ \\
\hline Stories overcome tediousness, and therefore increase my pleasure in the lecture. & 4.72 & $97 \%$ \\
\hline $\begin{array}{l}\text { Stories catch my attention and get me attached to the lecture such that I look } \\
\text { forward to being in the lecture to hear a new story. }\end{array}$ & 4.10 & $86 \%$ \\
\hline Stories provide examples explaining the scientific essence of that day's subject. & 4.76 & $97 \%$ \\
\hline $\begin{array}{l}\text { Stories add up to my expertise and heuristics, and provide a source of wisdom } \\
\text { that I shall use in my life. }\end{array}$ & 4.52 & $93 \%$ \\
\hline Stories increase my scientific background. & 4.17 & $86 \%$ \\
\hline Stories augment my overall knowledge. & 4.41 & $90 \%$ \\
\hline Actual stories cause more excitement and interaction than virtual ones. & 4.52 & $93 \%$ \\
\hline Actual stories are more beneficial than virtual ones. & 4.38 & $90 \%$ \\
\hline $\begin{array}{l}\text { Stories are nice and beneficial but at the cost of the lecture time, thereby the } \\
\text { scientific material is not fully covered. }\end{array}$ & 2.07 & $3 \%$ \\
\hline Stories are a waste of time and have no outcome, so there is no need for them. & 1.45 & $0 \%$ \\
\hline
\end{tabular}

Finally, students who have not been in the sections where stories are told were part of the survey (presented in Table 3) to gauge the interest within students in general, regarding storytelling in the class as a complementary part to augment the scientific material given to students. Since this group of students have not been through the experience, the table does not include a column highlighting the amount of students who have "totally agreed" or "agreed" with the statements.

Table 3. Assessment results of male students who have never been told stories in the lecture.

\begin{tabular}{|l|c|}
\hline \multicolumn{1}{|c|}{ Item } & Score \\
\hline Stories overcome tediousness, and therefore increase my pleasure in the lecture. & 4.61 \\
\hline $\begin{array}{l}\text { Stories catch my attention and get me attached to the lecture such that I look forward to } \\
\text { be in the lecture to hear a new story. }\end{array}$ & 4.33 \\
\hline Stories provide examples explaining the scientific essence of that day's subject. & 4.53 \\
\hline $\begin{array}{l}\text { Stories add up to my expertise and heuristics, and provide a source of wisdom that I } \\
\text { shall use in my life. }\end{array}$ & 4.22 \\
\hline Stories increase my scientific background. & 4.22 \\
\hline Stories augment my overall knowledge. & 4.32 \\
\hline Actual stories cause more excitement and interaction than virtual ones. & 4.17 \\
\hline Actual stories are more beneficial than virtual ones. & 4.05 \\
\hline $\begin{array}{l}\text { Stories are nice and beneficial but at the cost of the lecture time, thereby the scientific } \\
\text { material is not fully covered. }\end{array}$ & 2.51 \\
\hline Stories are a waste of time and have no outcome, so there is no need for them. & 1.35 \\
\hline
\end{tabular}

\section{Discussion}

The results of all three groups show that students overwhelmingly are in favor of having stories told in the classroom. It is not easy to draw conclusions of differences between the three groups. 
For the sake of analysis, some differences are highlighted. Male students who have been in the classes where stories are engaged favored most the fourth statement, i.e. they believed that stories add up to their heuristics and widen their scope of expertise. This indicates that the boys are quite keen in building on others, instead of learning it the "hard way"

As for the gender difference, female students rated the third statement as the highest, where they felt that stories could be a helpful tool in exemplifying the scientific essence of that day's subject. They were more passionate than the boys about having stories told in the class. The girls disagreed most with the statement that stories take up the lecture time, nor that they result in a reduction of the scientific content.

Students who have not heard in the classes are very eager to be part of the experience, so their highest rating was for the first statement. At the same time, they gave slightly lower scores in three items: stories increase their expertise and wisdom, actual stories create more student engagement than virtual ones, and actual stories are of more value than virtual ones. These might be understood as they have not heard the stories and felt the impact on them.

\section{Conclusions}

Storytelling in the classroom was utilized to augment the scientific material of an engineering design course given to students at the sophomore level. The stories employed were carefully picked and planned for the appropriate scientific content. Using personal experiences was much more relevant and created greater impact. The outcome of the experience was assessed through surveys of the student groups over four semesters. There were no significant discrepancies among the results. The results reveal an overwhelming support of the idea. All male and female students and even those who have not been through the experience were highly supportive of the idea, and never agreed that it is a waste of time. These results suggest the effectiveness of storytelling in achieving the following:

- Demonstrating ambiguous issues in the subject, by putting in examples and discussing analogies.

- Stimulating interest in the classes, as the community paying high tuition, is expecting more from the classes.

- Building ethical values, where education is sought to build values in addition to knowledge.

- Learning basic engineering principles intuitively, which are usually more effective than direct teaching of laws.

\section{References}

1. Baldwin, Lynne. "Editorial." Active learning in higher education. 2010 11: 163. DOI: $10.1177 / 1469787410379997$

2. Alterio, Maxine. "Using storytelling to enhance student learning." (2003).

3. Wlodkowski, Raymond J. Enhancing adult motivation to learn: A comprehensive guide for teaching all adults. John Wiley \& Sons, 2011. 
4. Kane, Ruth, Susan Sandretto, and Chris Heath. "Telling half the story: A critical review of research on the teaching beliefs and practices of university academics." Review of educational research 72.2 (2002): 177-228.

5. Abma, Tineke A. "Learning by telling storytelling workshops as an organizational learning intervention." Management Learning 34.2 (2003): 221-240.

6. Ross, Raymond. And thereby hangs a tale ... Article | Published in TES. 27 June 2008

7. Retrieved from http://www.tes.co.uk/article.aspx?storycode=2640887 (21.01.13) Airasian, Peter W., et al. "A taxonomy for learning, teaching, and assessing: A revision of Bloom's Taxonomy of Educational Objectives." Anderson LW and Krathwohl DR. New York: Addison Wesley Longmann (2001).

8. Jones, Sarah, and Patrizia Sanguedolce. "Developing High Order Thinking Skills Through Story Gathering." (visited 13.3.2014)

9. Robin, Bernard R. "Digital storytelling: A powerful technology tool for the 21st century classroom." Theory into practice 47.3 (2008): 220-228.

10. Alterio, Maxine, and Janice McDrury. Learning through storytelling in higher education: Using reflection and experience to improve learning. Routledge, 2013.

11. Felder, Richard M., and Rebecca Brent. "The ABC's of engineering education: ABET, Bloom's taxonomy, cooperative learning, and so on." Proceedings of the 2004 American Society for Engineering Education Annual Conference \& Exposition. 2004.

12. Gibbs, Graham, and Martin Coffey. "The impact of training of university teachers on their teaching skills, their approach to teaching and the approach to learning of their students." Active learning in higher education 5.1 (2004): 87-100.

13. Fox, Paula J. "Heart of a Teacher." (2009).

14. Palmer, Parker J. "The heart of a teacher identity and integrity in teaching. "Change: The Magazine of Higher Learning 29.6 (1997): 14-21. 